Columbia Law School

Scholarship Archive

\title{
Recovery for Pure Economic Loss in Tort: Another Look at Robins Dry Dock v. Flint
}

Victor P. Goldberg

Columbia Law School, vpg@law.columbia.edu

Follow this and additional works at: https://scholarship.law.columbia.edu/faculty_scholarship

Part of the Civil Law Commons, Contracts Commons, Law and Economics Commons, and the Torts Commons

\section{Recommended Citation}

Victor P. Goldberg, Recovery for Pure Economic Loss in Tort: Another Look at Robins Dry Dock v. Flint, 20 J. LEGAL STUD. 249 (1991).

Available at: https://scholarship.law.columbia.edu/faculty_scholarship/2642

This Article is brought to you for free and open access by the Faculty Publications at Scholarship Archive. It has been accepted for inclusion in Faculty Scholarship by an authorized administrator of Scholarship Archive. For more information, please contact scholarshiparchive@law.columbia.edu, rwitt@law.columbia.edu. 


\title{
RECOVERY FOR PURE ECONOMIC LOSS IN TORT: ANOTHER LOOK AT ROBINS DRY DOCK V. FLINT
}

\author{
VICTOR P. GOLDBERG*
}

\section{INTRODUCTION}

I

N Robins Dry Dock and Repair Co. v. Flint, 'the Supreme Court laid down the general proposition that claims for pure economic loss are not recoverable in tort. Although courts have sometimes ignored or distinguished Robins, its holding is still a central feature of tort law. In a recent en banc decision regarding claims by those injured by a chemical spill in the Mississippi River, the Fifth Circuit engaged in an extensive debate over the continued vitality of Robins and concluded (despite five dissenters) that it remained good law. ${ }^{2}$

The Robins rule is overbroad, lumping together a number of very different problems. Many of the claims barred by the economic loss doctrine are easily distinguishable from Robins. ${ }^{3}$ Of course the Robins rule need

\footnotetext{
* Thomas Macioce Professor of Law and Economics and codirector of the Center for Law and Economic Studies, Columbia University. I thank William K. Jones, Julie Nelson, Linda Silberman, and the participants in the Law and Economics Workshop at Georgetown University for comments on an earlier draft of this article. I also thank Kathy Simonetti and Catherine Valcke for research assistance.

1275 U.S. 303 (1927). The doctrine substantially predates Robins. See, for example, Cattle v. Stockton Waterworks Company, L. R. 10 Q. B. 453 (1875).

2 State of Louisiana Ex. Rel. Guste v. M/V Testbank, 752 F.2d 1019 (5th Cir. 1985). Shortly thereafter, Judge Breyer also followed Robins in a suit for economic losses arising from an oil spill; see Barber Lines A/S v. M/V Donau Maru 764 F.2d 50 (1st Cir. 1985). In its most recent treatment of the question of tort liability for economic loss, the Supreme Court cited Robins, although it did not find it necessary to address Robins's present status. It held that under the circumstances of the case a manufacturer was not liable in tort to a commercial customer for purely economic losses arising from a defective product. It did "not reach the issue whether a tort cause of action can ever be stated in admiralty when the only damages sought are economic." East River Steamship Corp. v. Transamerica Delaval Inc. 476 U.S. 858, 871 n.6 (1986).

3 Technically, since this was an admiralty case, Flint was a libellant and Robins a respondent.
}

[Journal of Legal Studies, vol. XX (June 1991)]

(C) 1991 by The University of Chicago. All rights reserved. 0047-2530/91/2002-0004\$01.50 
not give the wrong result in other cases of economic loss, but the doctrine gives no guidance as to why liability should be denied and fails to identify cases in which denial of recovery for economic losses is the wrong outcome.

Robins involved the claim of the charterer of a ship for compensation for the two weeks the vessel was out of service as a result of the negligence of a dry dock in performing scheduled repairs. Since the charter excused the charterer from paying rent to the owner while the ship was in dry dock, the charterer's losses were the difference between the rental rate to the owner and the market value of the ship's services for the two weeks it was out of use. The charterer sued the owner for breach of contract and lost $;{ }^{4}$ thereafter it sued the dry dock company and, after winning at trial and in the court of appeals, it lost in the Supreme Court. Justice Holmes held, in an opinion that Judge Wisdom has characterized as "a great judge . . . [having] an off-day," that the charterers had no damage claim in contract or in tort against the dry dock and that the complaint must be dismissed.

In the narrowest sense, Robins need not be classified as a tort case at all. All the parties-dry dock, owner, and charterer-were linked contractually. The losses that might result from the dry dock's negligence could have been allocated by the parties in their initial contracts. ${ }^{6}$ But the same basic problem can arise in the more common circumstance in which the wrongdoer is a stranger. For example, the triggering event might have been a collision with another vessel. The essential feature of Robins is that the tort injured two parties who were in a position to allocate a damage award between themselves in their initial contract.

All that was at stake in Robins was the plaintiff's claim for the favorable price of its charter. In eminent domain language, the plaintiff sued for the "bonus value" of the charter-the difference between the contract price and the market price. The scope of this article is restricted to the bonus value problem and to some very modest extensions. The article should be viewed as a self-contained piece of a larger project: a reexamination of the economic loss doctrine. The pivotal role played by Robins

${ }^{4}$ The Bjornefjord, 271 Fed. 682 (2d Cir. 1921).

5 State of La. ex Rel. Guste v. M/V Testbank 728 F.2d 748, 750 (5th Cir. 1984).

${ }^{6}$ Robins could really have been marginalized if subsequent courts had restricted its application to cases in which a plaintiff tried an end run around contractual limitations on its recovery. In fact, the courts did the opposite. Not only did the rule apply when the wrongdoer was a stranger, but it applied to a wide range of claims from a diverse group of third parties. If the charterer's delay resulted in late deliveries to a factory, for example, the Robins doctrine would have barred recovery for damages suffered by the factory, its employees, its customers, and so forth. 
in the development and continued maintenance of that doctrine justifies a detailed analysis of the case and of the bonus value problem. But it is important to emphasize that an understanding of Robins does not necessarily provide much of an insight into the myriad other problems classified under the heading of "economic loss." I suspect that Gary Schwartz is correct in arguing for a nonunitary approach:

I recommend that we abandon any effort to formulate any single general theory: for the economic loss problem, as I understand it, is multiform rather than unitary in character. Unfair competition differs from fraud, which in turn differs from negligent misrepresentation, which in turn differs from the negligent polluting of public fishing waters, which in turn differs from the lawyer's malpractice liability to his client (let alone to a range of third parties), which in turn differs from the destruction of buildings by fire, which in turn differs from compensating plaintiffs for lost income in personal injury suits. ${ }^{8}$

The organization of the article is as follows. In the next section, I summarize the facts of the case and its legal history. In the following section, I analyze the compensability of the bonus value, asking both whether the tortfeasor should be responsible for the loss and, if so, who should receive the compensation. Section IV is a brief digression. In Section V, I extend the discussion to some closely related questions: first, what should be the outcome if the charter had not excused the charterer from making payments while the ship was out of service; second, what if the contract had specified a sharing formula for compensating the owner? The Robins result does not, I suggest, carry over to these cases.

\section{THE RoBINS FACTS}

On September 13, 1913, Flint, Goering and Co. entered into a five-year charter agreement with Joh. Ludw. Mowinckel and Son, the owners of the Norwegian steamship Bjornefjord. ${ }^{9}$ Flint did not charter the ship for

\footnotetext{
${ }^{7}$ In an earlier article, I analyzed another problem that is typically classified as an economic loss problem-third-party tort claims against accounts; see Victor P. Goldberg, Accountable Accountants: Is Third-Party Liability Necessary? 17 J. Legal Stud. 295 (1988).

${ }^{8}$ Gary T. Schwartz, Economic Loss in American Tort Law: The Examples of $J$ Aire and of Products Liability, 23 San Diego L. Rev. 37, 38 (1986).

${ }^{9}$ Much of what follows is taken from the transcript of the trial (which includes the opinions of trial judge Henry Goddard and the commissioner he appointed, Mark Maclay). The trial was a brief one, the transcript being only five pages long. The testimony before the commissioner was considerably more detailed, but it was not reproduced for the Supreme Court. All page references to the trial transcript and the opinions of Goddard and Maclay are cited in 38 Cases and Points for 275 S. Ct. (hereafter cited as Cases and Points).
} 
its own use. Rather, it was an intermediary that subchartered to end users. The rental rate was 1,200 pounds per month. (The exchange rate at the time was 4.7555 dollars to the pound.) This turned out to be an excellent price for Flint, since the price of shipping services soared in World War I. The parties modified the charter in August 1917, increasing the rent $£ 250$ per month, to cover some increased expenses due to the war. This price, however, was still well below the current market price. Flint subchartered the ship in 1915 for twenty-six months at a rate of about $£ 11,200$ per month. It was rechartered to Norton, Lilly, and Co. for nearly $£ 16,995(\$ 80,819.72)$ per month for a sixteen-month term beginning on August 1, 1917. (All of these prices were reduced by a $2 \frac{1}{2}$ percent commission.)

On July 29, 1917, the owners sent the ship to Robins Dry Dock and Repair Co. for routine maintenance. In the course of replacing a damaged propeller, a Robins employee allowed the spare propeller to fall. A blade broke, and it was necessary to have a new propeller cast. As a result of the accident, the ship was held out of service an additional fourteen days. The charter and subcharter agreements included the identical cesser of hire clauses, which, with minor wording changes, are still used in most time charters today. ${ }^{10}$ The clauses held that hire would be suspended while the ship was out of service for specified reasons, including the ship's being in dry dock. Thus, during the fourteen days, Flint lost the difference between the rent Norton was supposed to pay to Flint and the rent Flint was supposed to pay to Mowinckel. The gross loss was $\$ 2,541.91$ per day, or $\$ 35,586.76$ for the fourteen days; Flint was relieved of paying $\$ 3,036.17$ for the fourteen days, so the net loss was $\$ 32,550.57 .^{11}$

\footnotetext{
10 "That in the event of the loss of time from deficiency of men or stores, breakdown of machinery, stranding, fire or damage preventing the working of the vessel for more than twenty-four running hours, the payment of the hire shall cease until she be again in an efficient state to resume her service; but should she in consequence put in to any port, other than that to which she is bound, the Port Charges and Pilotages at such Port shall be borne by the Steamer's Owners, but should the vessel be driven into Port, or to anchorage by stress of weather, or from accident to the cargo, such detention or loss of time shall be at the Charterer's risk and expense. . . That as the steamer may be from time to time employed in tropical waters during the term of this Charter, steamer is to be docked, bottom cleaned and painted whenever Charterers and Master think necessary, but at least once in every six months, and payment of the hire to be suspended until she is again in proper state for service" (Cases and Points, supra note 9, at 14, 32).

"A number of other cases arose during the war in which the charterer had an extremely favorable price. In Hines v. Sangstad S. S. Co., 266 F. 502 (1st Cir. 1920), the owner's damage was $\$ 2,669.95$, and the charterer's, $\$ 15,473.32$; in Siberia S. S. Corp. v. S. S. Binghamton, 271 F. 69 (2nd Cir. 1921), the owner's damage was $\$ 13,750.00$, and the time charterer's damage, $\$ 20,824.98$. In The Aquitania, 270 F. 239 (S.D.N.Y. 1920), the owner's damage was $\$ 1,000,000$ (including tangible property damage), and the time charterer's loss was $\$ 1,700,000$.
} 
Flint, obviously, wanted to be compensated for these losses. It realized immediately that it was in a somewhat awkward legal position. It wrote a letter to the ship's captain, on August 10, four days before the ship had been released, expressing concern over the delay and informing the captain that it was suffering damages at the rate of $\$ 75,000$ per month. ${ }^{12}$ It intended to recover the money from Robins but recognized that there might be legal difficulties:

We feel that under the facts now before us the Robins Company should pay our claim and we intend to endeavor to collect it from them and purpose to send them a notice to that effect if you have no objections.

But our Attorneys tell us that under the peculiar circumstances it is doubtful if we can collect direct from Robins as we have no contractual relations with them, and that to protect ourselves we must make claim against your owners for our damages so that you and they may then recover the amount from the Robins people and settle with us. In other words, that you and your owners should collect our damages as well as yours from the Robins people and pay over to us our damages.

We accordingly have no alternative but to herewith make formal claim upon your owners through you for whatever damages we have suffered or may hereafter suffer by reason of the above detention and loss of use of the vessel.

We have explained to you, however, and herewith repeat, that if the Robins Company is responsible we naturally do not desire your owners to lose money, and we will do everything possible to force Robins to pay and will cooperate fully to this end. ${ }^{13}$

For reasons that are not entirely clear, the owners of the Bjornefjord did not cooperate with Flint. They entered into a settlement with Robins on December 7, 1917, about four months after the accident occurred. The owners received $\$ 3,271.21$ (approximately the lost rent) and gave Robins a release from all further liability to the owners. ${ }^{14}$ However, the release did not affect Robins's possible liability to Flint. ${ }^{15}$

Flint then brought suit against the owners of the Bjornefjord. Its argument was not that the owners had failed to represent its interests following the accident. ${ }^{16}$ Rather, Flint argued that the owners had failed to

12 It wrote to Robins on the same day to inform the dry dock that "we hold you liable and responsible for our damages either direct or to us through the owners" (Cases and Points, supra note 9, at 16).

13 Id. at 13.

14 Id. at 6.

is Id. at 15 .

${ }^{16}$ The Bjornefjord, supra note 4. 
"maintain her in a thoroughly efficient state" as required in clause one of the charter agreement, and hence the remedies specified in the cesser of hire clauses did not apply. Learned Hand dismissed the suit at trial on the grounds that the delay was caused by one of the defined conditions and that the contract defined the remedy. ${ }^{17}$ The appellate court affirmed on slightly different grounds. The owner, said the court, met its duty by exercising reasonable and ordinary care to restore the vessel by using an "experienced, reputable, and fully equipped ship repair concern.",18

Flint filed its suit against Robins in $1920 .{ }^{19}$ At the trial, Judge Goddard held that the central issue was whether the charterer's interest was a property interest: "Is the right to the use of a vessel a property right which the law recognizes and protects? If a third party, not the owner of the vessel, through negligence, deprives the charterer of this right, has he any remedy? . . . If he has a property right, is he not entitled to a direct remedy? An analogy might be found in cases of eminent domain where the lessee, as well as the owner, is held entitled to compensation. If the charterer has a property interest in the vessel, then he has a right of action against one who damages his property." ${ }^{20}$ Since Flint had a property right, he argued, it was entitled to compensation and he referred the case to a commissioner to reckon the damages. ${ }^{21}$ The commissioner found the damages of $\$ 32,550.57$ plus prejudgment interest (for August $1,1917$, through September 1,1925$)$ of $\$ 15,787.03$; the total judgment, therefore, was $\$ 48,337.60$. $^{22}$

The decision was affirmed on appeal to Judge Mack (joined by Learned Hand, who had by this time been elevated to the Court of Appeals). The reasons adduced, however, were different. Judge Mack rejected Flint's contract claim (ignored by Judge Goddard) that was based on the notion that Flint was a third-party beneficiary of the contract between the dry dock and the owners. ${ }^{23}$ Judge Goddard's assertion ${ }^{24}$ that the charterer had a property right was also rejected..$^{25}$ Nonetheless, Judge Mack held that Robins's "liability for its tortious act is the actual damage done to

${ }^{17}$ Id. at 683 .

18 Id. at 683.

19 I suspect that it filed this suit before resolution of its suit against the owners because the statute of limitations was about to expire. The case against Robins was not heard until October 1923.

${ }^{20}$ Cases and Points, supra note 9, at 21-22.

21 Goddard relied upon The Aquitania, supra note 11.

22 Cases and Points, supra note 9, at 32.

${ }^{23}$ Robins Dry Dock v. Flint, 13 F.2d 3, 4 (2d Cir. 1926).

24 Bjornefjord 1924 A.M.C. 740, 744.

${ }^{25}$ Robins, supra note 23 , at 5 . 
the combined interests in the ship. The measure of the total recovery is the market value of the loss of the use. ${ }^{, 26} \mathrm{He}$ continued: "If there had been no charter, the entire loss would have been sustained by the owner; therefore he could have recovered that amount for himself. The wrongdoer has no interest in and should not benefit because of the contractual obligations of the shipowner to the charterer or the absence of any liability of the owner to the charterer for respondent's negligence." 27 The existence of a below-market charter, in short, should not let the tortfeasor off the hook. Robins is liable for the market value of the loss of use, and that liability should be unaffected by the existence of the charter. "[T]he result reached involves no injustice to [Robins]. Its liability for its tortious act is the actual damage done to the combined interests in the ship.",28

The owner, Mack suggested, could be viewed as a trustee for the charterer, collecting the entire damage amount from Robins and returning to Flint the amount in excess of the contract rent. However, since the owner had already settled its claims, Mack had to justify Flint's suing directly for its injuries. "It is unnecessary to determine in the instant case whether the charterer's right to recover for his loss is direct against the wrongdoer, enforceable by a libel independent of that which the shipowner but for the release could have brought for his damages, or whether it is indirect based upon the equitable obligation of the shipowner to the charterer." 29 The right result for Mack had two components. First, the tortfeasor had to bear the full costs of the incident; and, second, that the division of the award be determined by the price specified in the initial charter. He was not particularly concerned with the path used to reach this result.

Justice Holmes, like Mack, dismissed the notion that Flint was a thirdparty beneficiary to the Bjornefjord-Robins contract. The district court's notion that the charterer had a property right in the vessel "although it is not argued that there was a demise, and the owners remained in possession," 30 was also dismissed without discussion. Holmes argued

${ }^{26}$ Id.

${ }^{27}$ Id.

28 Id.

29 Id . at 6.

30 Robins, supra note 1 , at 308 . For those readers whose admiralty vocabulary has become somewhat rusty, a demise (or bare-boat) charter is one in which the owner "part[s] entirely with the command, possession, and control of his vessel." 2B Benedict on Admiralty, at $\S 52$ (7th ed. rev. 1990). The captain and crew, for example, are hired by the charterer and he bears responsibility for their decisions (including liability for collisions). Under a time charter, the owner provides captain and crew. It has long been established that the demise charterer has a property interest pro hac vice (for all practical purposes). In their treatise, Gilmore and Black cite cases on this point predating Robins by more than half a century; Grant Gilmore \& Charles L. Black, Jr., The Law of Admiralty, at $\S 4-23$ 
that the damage to the propeller was a wrong only to the owner, even though the charterer's loss flowed directly from that wrong. He cited the general rule that "a tort to the person or property of one man does not make the tortfeasor liable to another merely because the injured person was under a contract with that other, unknown to the doer of the wrong." 31 Thus, Flint cannot recover because there is no contract duty (it is not a third-party beneficiary), no property right (the charter is a time charter, not a demise charter), and no tort duty (no privity and no responsibility for pure economic loss).

Holmes then concludes by rejecting Judge Mack's notion that the charterer might recover or some variation on the owner-as-trustee argument:

The decision of the Circuit Court of Appeals seems to have been influenced by the consideration that if the whole loss occasioned by keeping a vessel out of use were recovered and divided a part would go to the respondents. It seems to have been thought that perhaps the whole might have been recovered by the owners, that in that event the owners would have been trustees for the respondents to the extent of the respondent's share, and that no injustice would be done to allow the respondents to recover their share by direct suit. But justice does not permit that the petitioner be charged with the full value of the loss of use unless there is some one who has a claim to it as against the petitioner. The respondents have no claim either in contract or in tort, and they cannot get a standing by the suggestion that if some one else had recovered it he would have been bound to pay over a part by reason of his personal relations with the respondents. ${ }^{32}$

Two things should be noted about Holmes's opinion. First, it is short on justification. Flint could recover if it had a property interest; it did not; ergo, no recovery. There is no attempt to question the doctrines that, in Holmes's perception, bar recovery. Second, Holmes does not say how the claim of the owners and charterers interact. Even though both parties raised the question in their briefs, ${ }^{33}$ Holmes does not say whether the owners could have received compensation for the market value of the

(2d ed. 1975). Thus, Holmes appears to be saying that if Flint had had a demise charter, it clearly would have won. A mere time charter, however, does not give Flint a property interest.

31 Robins, supra note 1, at 309.

${ }^{32}$ Id.

${ }^{33}$ See Cases and Points, supra note 9, Brief for Petitioner, at 16-18; and Brief for Respondents, at 4 . ("What might have happened if the suit had been brought by the owner and the owner had refused to turn over to the charterers their proper share of the recovery is not in issue in this suit.") 
ship had they chosen to pursue their legal remedy. ${ }^{34} \mathrm{I}$ will return to that question in Sections IV and V. ${ }^{35}$

\section{Compensation for the Bonus Value}

It is important to recognize what is at stake in this dispute. Flint's claim is that it lost a favorable price-the bonus value. Robins damaged an asset and the charter determined how that loss would be divided between Mowinckel and Flint. The issues are the magnitude of Robins's liability, the apportionment of its liability, the extent to which these are affected by agreements entered into by the parties before the negligent act occurred, and the extent to which these are affected by the form in which the claims are pressed (that is, should it matter if Mowinckel sued as a trustee for Flint rather than Flint suing on its own behalf).

It is useful to begin the analysis by recalling Judge Goddard's syllogism: (1) the problem is analogous to the treatment of the taking by eminent domain of the leasehold interest; (2) if the charterer had a property interest, it would be entitled to compensation by anyone who damages that property; (3) the analogy establishes that the charterer did have a property right; (4) therefore, it should be compensated. Mack and Holmes rejected the conclusion by denying the third step. One can reject Goddard's argument while nevertheless finding his analogy instructive.

In this section I will reconsider Goddard's analogy. My analysis suggests that Goddard's conclusion was wrong: charterers should not recover. (It is less clear, however, as to the outcome of a suit by the owner for recovery of the bonus value.) Oddly, Goddard did not suggest an even more appropriate analogy, the tenant's right to sue a tortfeasor for damage to its leasehold interest. That line of inquiry is pursued in the last part of this section. That discussion, while it is not conclusive, provides some support for the conclusions suggested by the eminent domain analogy.

\footnotetext{
${ }^{34}$ Nor does it say how a suit by Flint against the owners claiming a breach of trust should come out. The argument would be that the owners had a duty to represent the charterer's interest in the settlement negotiations with Robins. Robins' counsel notes in its brief that the tort it is accused of is roughly of this type: "The so-called tort as to the charterers seems to have consisted in the petitioner's [Robins] obtaining a release from the shipowners without paying the full amount of the damages that the shipowners might possibly have recovered"' (Cases and Points, supra note 9, Brief for Petitioner, at 20).

35 Holmes was similarly opaque in an eminent domain case a quarter century earlier. In Emery v. Boston Terminal Co., 178 Mass. 172, 185, 59 NE 763 (1901), he denied compensation to a tenant for the loss of the expectation of renewal, but he implied that the owner might have sued directly for those losses which he was denying plaintiffs.
} 


\section{A. The Eminent Domain Analogy}

Both the landlord and tenant have a constitutionally protected interest in leased property taken under eminent domain. ${ }^{36}$ The government must pay compensation based on what the land would be worth if it were subject to unified ownership (the undivided fee rule). ${ }^{37}$ The award is then apportioned between the landlord and tenant according to their respective interests. For a standard space lease, the landlord would receive the present value of the stipulated rent for the duration of the lease plus the reversion and the tenant would receive the market value of the leasehold interest-the bonus value.

The undivided fee rule makes good economic sense in both the eminent domain and tort context. The social harm done is measured by what is taken or destroyed, and the magnitude of the harm is unaffected by the existence of the leasehold..$^{38}$ If we want governments (or potential tortfeasors) to be confronted with the true social costs of their activities, the undivided fee rule does just that, at least in principle. ${ }^{39}$ We will return to the qualification below.

The rule of division makes less sense. This is illustrated by the fact that parties almost invariably contract around it. Leases usually include condemnation clauses that undo the constitutionally generated rule of division. Where only the bonus value is at stake, the clauses generally specify that, in the event of a government taking of the entire leased property, the lease terminates and, therefore, the entire condemnation award goes to the landlord. ${ }^{40}$

The unpopularity of the default rule is easily understood. The tenant's share is the bonus value of the lease. If conditions improve after the lease is signed, the bonus value will turn out to be positive; if conditions deteriorate, it will turn out to be negative. But, so long as there is no systematic bias, when the parties enter into the lease, the expected value

\footnotetext{
36 Victor P. Goldberg, Thomas W. Merrill, \& Daniel Unumb, Bargaining in the Shadow of Eminent Domain: Valuing and Apportioning Condemnation Awards between Landlord and Tenant, 34 UCLA L. Rev. 1083, 1086-87 (1987).

37 Id. at 1092.

38 This is a slight simplification; the nuances are considered in id. at 1094-1106.

39 Bishop and Sutton make this argument and use Robins to illustrate the point: "[T]he existence or nonexistence of a contract is irrelevant to the calculation of the damages needed to induce allocative efficiency." William Bishop \& John Sutton, Efficiency and Justice in Tort Damages: The Shortcomings of the Pecuniary Loss Rule, $15 \mathrm{~J}$. Legal Stud. 347, 351 (1986).

${ }^{40}$ Again, this presentation glosses over some of the complexity; see Goldberg, Merrill, \& Unumb, supra note 36 , at 1106-20.
} 
of the bonus is zero. ${ }^{41}$ This proposition is just a variation on the efficient market hypothesis in its weakest form. The parties make an informed guess about future market conditions when negotiating the rent. Sometimes they will be overly optimistic and sometimes overly pessimistic. But, on average, they will get it about right.

Since the expected value of the leasehold interest is zero, the tenant does not give up much by surrendering its claim to the landlord when entering into the lease. But something important is gained-the costs, legal and otherwise, of hassling over division of the award are avoided. By agreeing, in effect, not to contest the landlord's claim to the entire award, the tenant increases the size of the pot available to the two parties. $^{42}$

\section{B. Charter Price versus Market Price}

The first pass using the eminent domain analogy therefore suggests that Holmes's decision was correct but that the net result was wrong. Flint should end up without compensation, but the ship's owners should have received a larger settlement-a matter about which the courts could do nothing since the question of Robins's liability to the owners never reached the courts. However, it is possible to rationalize an outcome in which the owner receives the entire award and that award is based on the contract price rather than the current market price. The costs of deviating from the undivided fee rule are likely to be low, and it is at least plausible that basing recovery on the charter price will economize on measurement costs.

Recall that the virtue of assessing the wrongdoer the market value of the damage is that this would induce the proper amount of care. In the tort context, but not the eminent domain context, the contract price would do just about as well. The reason for this is a variation on the efficient market argument offered above. The tortfeasor does not usually know whether property is under contract and, if it is, what the terms might be. ${ }^{43}$ If it is assessed the contract value of the damages, sometimes the assessed damages will be too high and other times too low; but if there are no system-

41 Id. at 1110 .

${ }^{42}$ Of course, even after they have entered into such an agreement, tenants will occasionally contest the award. Courts have used a number of doctrines (for example, the law abhors a forfeiture) to abet tenants in avoiding the consequences of their condemnation clauses; see id., at 1120-25.

${ }^{43}$ In Robins, the dry dock was not a stranger, and information about the special terms could have been conveyed to the dry dock. Generally, however, the wrongdoer would be a stranger. 
atic biases, the expected value of the contract and market damages should be about the same. In periods of rapidly rising prices (as in Robins), the contract prices would on average be a bit too low, and when prices were rapidly falling the contract prices would be too high. Thus, the tortfeasor's incentives to take care might be somewhat distorted in periods of rapid, systematic price changes. Generally, though, the incentive effects for the tortfeasor are basically unaffected by whether the damages are reckoned by the contract value or the market value.

In the eminent domain context, the contract value versus market value choice does matter. Typically, the tortfeasor did not know the contract terms and therefore presumed that the expected value of damages it caused would be the market value. A government exercising the power of eminent domain would not operate behind this veil of ignorance. If paying the contract price satisfied the constitutional obligation, governments would have an incentive to skew their takings, condemning property with a positive bonus value and eschewing parcels with a negative bonus value. ${ }^{44}$

Assuming that little is lost by reckoning the tortfeasor's liability by the contract value, what, if anything, is to be gained by doing so? The answer is that it saves the costs of measurement. To determine the damages caused by Robins's negligence, we just look at the lease price and calculate the price for fourteen days. This is much easier and cheaper than taking testimony on the market value of the ship. This point was nicely underscored in the commissioner's damage measurement. Flint introduced evidence to indicate that the market price at the time of the accident was even higher than the rental specified in the subcharter with Norton. The commissioner accepted the evidence but then chose to use the subcharter price, presumably because he was more comfortable with that number than with the opinion evidence offered by the ship broker called by Flint. ${ }^{45}$

\section{Temporary versus Permanent Harm}

The measurement problem is resolved quite differently if the damage is permanent. We have to some degree been comparing apples and or-

\footnotetext{
44 Of course, some torts are intentional and some takings inadvertent (for example, flooding caused by a government project). Nonetheless, in most instances the characterization in the text is correct.

45 At the hearing to estimate damage, Flint introduced testimony from a ship broker that the market rate for a ship like the Bjornefjord in the first half of August 1917 was between $\$ 87,000$ and $\$ 93,000$ per month (about 10 to 15 percent above the rate in the Norton sub-
} 
anges. For the permanent taking, the damages are measured by the market value, while for the temporary harm caused by the tortfeasor, the damages are measured by the contract price. What then of the permanent harm or temporary taking? If the tortfeasor caused permanent harm (for example, the ship sinks), the charter would almost always be drafted so that such an event would result in termination (just as the lease would terminate when the parcel is condemned) $;{ }^{46}$ consequently, the undivided fee rule would apply, and the owner would receive the entire award, measured by the ship's market value at the time it was destroyed. ${ }^{47}$

Temporary takings are rare, but they do occur. ${ }^{48}$ The default rule for a temporary taking is that the tenant remains liable to the landlord for the contract rent and the government compensates the tenant alone for the fair market value of the leasehold. However, if the parties have a standard space lease, the lease will usually include a condemnation clause that terminates the lease; the landlord would then receive all the compensation as measured by the current market value. ${ }^{49}$

Thus, the added complications arising from comparing apples with apples do not change the moral of Judge Goddard's analogy. The efficient rule (if the tenant or charterer has not installed substantial improvements) $)^{50}$ is for the tenant/charterer to receive nothing and for the owner to receive the market value except when measurement costs make it

charter). Cases and Points, supra note 9, at 29. It does not appear that Norton filed a suit to recover the loss of its bonus value.

46 Both the charter and subcharter in Robins included a clause that made the charter "null and void" if the underwriters condemned the steamer. Cases and Points, supra note 9 , at 14,32 .

47 The general rule is that the wrongdoer is liable for the value of the ship at the time of destruction; see Gilmore \& Black, supra note 30, at $\$ 7-18$; see also Asphalt International, Inc. v. Enterprise Shipping Corporation, S.A., 667 F.2d 261 (2d Cir. 1981). Vinland, 1925 A.M.C. 1141, was a significant exception. There a commission hearing claims for American interests in vessels sunk by the Germans in the First World War held that market value determined the German liability but chose to ignore the termination clause and divided the award as per the charter terms. Of course, for this class of cases it is almost certain that the charter price was below the market price at the time of the sinking. Therefore, the commission did not have to deal with negative bonus value charters. Vinland, which was decided in the period between Goddard's and Holmes's decisions in Robins, drew upon Goddard's decision to justify the outcome.

48 A number of cases arose during the Second World War when the government temporarily converted leased property to wartime uses; see, for example, United States v. General Motors Corp., 323 U.S. 373 (1945).

49 Goldberg, Merrill, \& Unumb, supra note 36, at 1118-20.

${ }^{50}$ For time charters that proviso would almost always hold. For leases of real property, tenant improvements will often be important and condemnation clauses become more complicated as the parties try to compensate the tenant for such improvements without encouraging excessive strategic behavior in a condemnation proceeding; see $i d$. at 1112-16. 
practical to use the contract price. Robins, arguably, fits within that exception. $^{51}$

\section{Negative Leasehold}

Giving Flint an action for market value would create another set of complications. In the actual case, Flint had a large positive bonus, and it is natural that he would try to get compensated through the courts. But suppose that the market price of shipping had fallen after he had entered into his lease. The tort would release him from an onerous obligation; Flint would have the equivalent of a "negative leasehold." Thus, if Flint could sue when the bonus value was positive, but did not have to disgorge when the bonus value was negative, we would have an asymmetric result. ${ }^{52}$ The wrongdoer would be liable to the owner for the contract rent regardless. If the market price had risen, the wrongdoer would also have been liable for the bonus value. If the market value had fallen, however, it would not have had its liability reduced. The wrongdoer would pay the positive bonus value but not be credited for taking the negative bonus value. Since the expected value of the bonus is zero, wrongdoers as a class would pay too much. ${ }^{53}$

The same sort of problem would arise if the owner had a choice of suing for the contract rent when the bonus value was negative or the market value when the bonus value was positive. The case in which the owner sues as trustee for the charterer is a hybrid of these two. If the wrongdoer cannot compel the parties to present their claims as a package, then it is vulnerable to selective litigation. This problem is avoided in the eminent domain context where the action is against the land itself rather than the interests different parties have in that land. ${ }^{54}$ The government's liability is fixed irrespective of the maneuvering of the parties.

Tort defendants might attempt to protect themselves from a strategy

51 The charter rate establishes at least prima facie evidence of the magnitude of the loss. See The Brand, 224 F. 391 (3d Cir. 1915). A court could determine in a Robins-type case that the charter price so clearly departed from the market price that it would take other evidence on the market price.

52 In the eminent domain context, "[n]o cases have been found, and it is unlikely that any court will so decide at the present time, that the lessee contribute or pay the negative value of his interest upon a complete taking." Alan N. Polasky, The Condemnation of Leasehold Interests, 48 Va. L. Rev. 477, 492 (1962).

53 If this overpayment were anticipated, then it would be incorporated in the initial charter price. The charterer would buy the use of the vessel for a fixed period plus a lottery ticket that pays off if there is a tortiously caused delay and a positive bonus value.

${ }^{54}$ See Goldberg, Merrill, \& Unumb, supra note 36, at 1092. 
of selective participation by various procedural devices-for example, compulsory joinder. I will not explore the efficacy of any such defensive strategy. ${ }^{55}$ It is sufficient to note that, if we assess the wrongdoer the positive bonus value, then there should be some mechanism in place to credit the wrongdoer for taking a negative bonus value lease. This follows both on efficiency grounds-the asymmetric treatment of the bonus would result in penalties that were, on average, too high-and, perhaps surprisingly, on equity grounds as well.

Notice how this argument turns the equity argument on its head. I suspect that most readers of Robins believe that Robins got away with something and that the result was unfair to charterers. ${ }^{56}$ That is why Judges Goddard and Mack try so hard to avoid the consequences of the economic loss doctrine. For Mack the ideal resolution of the case would have had the owners recovering the bonus value as trustees for Flint. But, if a wrongdoer would not get credit for destroying the negative bonus value, Mack's rule would lead to overcompensation for the class of charterers. A rule that appears fair in the context of a single, isolated case becomes unfair in the broader context.

This line of argument suggests that either of two routes would be appropriate. Either there should be no recovery for the bonus value (the charter price should be used to reckon damages), or the market price of the "undivided fee" should be used (which would take into account both positive and negative bonuses). In either case, the magnitude of the damages is a matter of tort law, and the division of damages is a matter of contract.

\section{E. The Analogy Not Taken}

Judge Goddard ignored a more obvious analogy. Instead of invoking a governmental taking of leased property, he could have asked what happens when a third party's negligence results in an interference with the use of leased property. The answer is a complicated amalgam of the common law, statutes, and lease terms, with an overlay of insurance.

Consider the following hypothetical case which closely tracks the Robins facts. Smith has a five-year lease from Jones at $\$ 1,000$ per month with a current market value of $\$ 3,000$ per month. Brown negligently causes a fire that results in Smith's shop being closed for one month. The lease

\footnotetext{
55 In his dissent in Agwilines, Inc. v. Eagle Oil \& Shipping Co., 153 F.2d 869, 873 (2d Cir. 1946), Charles Clark, the father of the federal rules of civil procedure, discusses some procedural devices that could be used to combine the claims of the owner and charterer.

${ }^{56}$ See, for example, Bishop \& Sutton, supra note 39, at 350-51.
} 
has a rent abatement clause that allows Smith to stop paying rent in the event that the shop is closed because of fire damage. Is the wrongdoer liable for $\$ 1,000$ or $\$ 3,000$ ? To whom is it liable? Robins would appear to resolve this question by paying $\$ 1,000$ to the owner and nothing to the tenant. ${ }^{57}$ Landlord/tenant law and modern leases would almost certainly have Brown pay $\$ 1,000$ to Jones (the landlord) and $\$ 2,000$ to Smith (the tenant).

If the wrongdoer's act deprived a tenant of the use of leased property, the common-law rule was very simple. The tenant had a property right in the leasehold and the landlord a right in the reversion. If, say, the property was rendered worthless in perpetuity, the lessee was still liable to the landlord for the contract rent. If a third party was responsible for the damage, the tenant could sue for the damage to the leasehold interest and the landlord for the reversion. ${ }^{58}$ If the damage were temporary (so that it ceased before the lease ended), then the landlord would have suffered no harm (it would still be paid rent as per the lease). The tenant would receive compensation for the market value of the leased property for the period that it is out of use; that is, the tenant would receive, in effect, the contract rent plus the bonus value. ${ }^{59}$ This is essentially the same as the eminent domain rule.

A rent abatement clause, the landlord/tenant analog to the cesser of hire clause in Robins, is an adjustment between the landlord and tenant which should leave unaffected the sum of the wrongdoer's liability to the two. While courts need not take such a clause into account when determining the respective awards of landlord and tenant, in practice, they do. ${ }^{60}$

In both the eminent domain and tort contexts, the formal rules of landlord/tenant law are not particularly helpful. In both contexts, the formal law is usually undone by the lease terms. In the tort context, the leases rarely deal specifically with the question of the liability of a third party to the landlord and tenant, respectively. Friedman on Leases, the leading treatise, has an extensive treatment of the problems arising from the damage and destruction of leased premises, the landlord's and tenant's liability to each other for their negligence,${ }^{61}$ and of the interrelation be-

\footnotetext{
57 There is some ambiguity since Robins only deals with the claim of the charterer. Holmes did not explicitly deal with a suit by the owner for more than the contract price.

${ }^{58}$ Chubb Group of Ins. v. C.F. Murphy \& Assoc., 656 S.W.2d 766 (Mo. App. 1983).

59 See 1 Restatement (Second) of Property, $\$ 5.2$ comment g, and $\$ 5.4$ comment i (1977).

${ }^{60}$ Lemon v. Fein, 467 So. 2d 548 (4th Cir. 1985).

61 Milton R. Friedman, I Friedman on Leases, §§ 9.1-9.10 (2d ed. 1983).
} 
tween the insurance obligations of landlord and tenant. ${ }^{62}$ However, it is silent on the rights of the parties against a third-party wrongdoer.

Modern leases generally override the common-law rule that would compensate the tenant if the property had been destroyed. Usually parties allow the lease to terminate in this instance just as it would for a permanent taking. Up to this point the analogy brings us to the same conclusion as before. If there is complete destruction of the leased property, the wrongdoer would be liable only to the owner and the liability would depend on the market value, not the contract price.

Beyond this, it gets tricky. The drafting problem is considerably more difficult if the property is not totally destroyed. Often, one or both parties is given the option of repairing the destroyed property or terminating the lease if damages are severe enough. ${ }^{63}$ (The determination of severity could be left to a third party like the insurance underwriter.) Since the landlord and tenant usually have insurance and since the proceeds of insurance are generally set aside to finance the repair of the damaged property, the division of the award between the two parties is often irrelevant. ${ }^{64}$

Nonetheless, despite the fact that modern leases undo most of the common law (and constitutional law) of leaseholds, they continue to leave largely intact the rule making third-party wrongdoers liable to the two separate interests for a temporary disruption. If the disruption occurs entirely within the term of the lease (that is, there is no interference with the reversion), then the tenant has a claim against the wrongdoer based on the market value of the property during the disruption. If there is a rent abatement clause, the tenant would end up with the bonus value. That is precisely the outcome that was rejected in Robins.

Why the difference? The different treatment between the eminent domain and tort claims of the tenant probably stems from the disparate treatment of consequential damages. In a tort action, the tenant can recover for lost profits, including consequential damages, ${ }^{65}$ but consequential damages are not recoverable for a taking. ${ }^{66}$ For vessels under charter, courts will not usually recognize consequential damages. Damages are lost profits, and "the best measure of loss of earnings is the amount of

\footnotetext{
62 Id. at vol. $3, \S 38.1$.

${ }^{63}$ Id. at vol. $1, \S \S 9.2-9.9$.

${ }^{64}$ The insurer would be subrogated against the tortfeasor.

${ }^{65}$ See Lemon, supra note 60; Chubb Group Ins., supra note 58; and Berlin Development Corporation v. Vermont Structural Steel, 250 A 2d 189 (Vt. 1968).

66 See 4A Julius L. Sackman \& Patrick J. Rohan, Nichols on Eminent Domain (3d ed. rev. 1990), \& 14.01 .
} 
profits which the owner would have realized had the vessel been able to perform under the charter. ${ }^{, 67}$ In the lease context, since the tenant could recover anticipated profits, it would make no sense to adjust this amount by breaking out the bonus value separately. Its expected value is again zero, and treating it as part of the anticipated profits means that there is one less magnitude to measure. It is cheaper to award anticipated profits that implicitly include the bonus value than it would be to explicitly adjust the profits to exclude the bonus value.

\section{A Brief Digression: Simpson v. Thomson}

A narrow interpretation of Robins is that it only concerns a question of standing. The charterer has suffered no direct economic loss and cannot sue. However, the charterer might have been able to recover its losses indirectly if the owner had sued. The charter could have obligated the owner to sue third parties and could have specified a rule for dividing the award. Thus, it might not matter much if the court got it wrong. The next generation of charters (contracts) would be revised to yield the correct outcome. Doctrine could evolve along its own path while the law created by the parties evolved in a different direction.

That outcome would not necessarily be bad. It is, after all, roughly what happened in landlord/tenant law. It does create some difficulties, however. Contracting around the inappropriate rule might be expensive. ${ }^{68}$ Also, the application of inapt doctrine to new fact situations might generate considerable transitional costs.

Regardless of whether it is good or bad, the separate evolution of doctrine and practice can muddy the debate. A good example of this is provided by Simpson $v$. Thomson, ${ }^{69}$ a case discussed at great length in Robins's brief ${ }^{70}$ and modern economic loss cases (especially in the Commonwealth). ${ }^{71}$ The basic facts are simple. Two ships (A and B) col-

67 Sabine Transportation Company, Inc. v. Steamship Esso Utica, 1955 A.M.C 2102, 2106. This case involved a negative bonus. The charterer was a subsidiary of the owner, and while the damaged vessel was being repaired the owner hired another vessel at a price below the charter price. The commissioner held that the owner could recover for the full charter value.

68 If parties are uncertain that the courts will enforce their variations on the default rule, that adds to the expense.

693 App Cas 279 (1877).

${ }^{70}$ Cases and Points, supra note 9, Brief for Petitioner, at 13-15. The case was cited in passing by Mack but not cited at all by Holmes or Goddard.

71 See, for example, Weller v. Foot \& Mouth Disease Research Institute, (1965) [1966] 1 Q.B. 569; 3 All E. R. 560; Spartan Steel \& Alloys Ltd. v. Martin \& Co., [1973] 1 Q.B. 27; SCM (United Kingdom) Ltd. v. W.J. Whittal \& Sons Ltd. Court of Appeal, Civil Division, 1970 [1971] I Q.B. 337. 
lided; A was at fault, and B suffered a total loss. Ship B recovered from its underwriters who then sued $A .^{72}$ Normally, the underwriters would be subrogated to $B$ and the recovery would be routine. The twist was that A and B were owned by the same person. Since the owner could not sue himself, the underwriters could not be subrogated. The underwriters tried to sue on their own account, but the court would have none of it. The underwriters suffered only an economic loss and could not be compensated for their loss.

The leading British treatise on marine insurance contains a lengthy discussion of Simpson $v$. Thomson ${ }^{73}$ that is entirely in terms of doctrinal questions; it is silent on whether the rule survives in practice. The silence is not based on ignorance of practice but rather on the notion that the actual practice of the parties is irrelevant. In fact, the practice is to undo the decision by including in the insurance contract a "sister ship clause" that, in effect, allows the vessel to sue another vessel owned by the same owner. The clause is described in the same treatise without even a cross-reference to the discussion of Simpson $v$. Thomson. ${ }^{74}$

Thus, the outcome in Simpson was clearly wrong. Had they thought of it, the parties would have wanted to give the insurer the same right of subrogation for sister ships that it would have in collisions with strangers. That does not, however, mean that the decision was necessarily wrong. One could plausibly argue that there are benefits to defining a small class of people who could directly sue the wrongdoer and forcing others to channel their claims through that group. ${ }^{75}$ For my purposes, it is unnecessary to decide whether the decision could be justified on that ground. All I want to do here is underscore the point that, in Robins, Holmes might have been quite indifferent to the merits of the outcome. His concern

72 There is an added complication. A's liability was limited by statute so the underwriter's recovery would come out of a fixed pot to be shared with the cargo owners, master, and crew.

73 British Shipping Laws 10, The Law of Marine Insurance and Average II, at ff 1216-19 (Arnould's 15th ed. 1961).

74 "'[S]hould the vessel hereby insured come into collision with or receive salvage services from another vessel belonging wholly or in part to the same owners, or under the same management, the assured shall have the same rights under this policy as they would have were the other vessel entirely the property of owners not interested in the vessel hereby insured." Id. at I 782 .

75 Mario Rizzo has suggested that the bar on recovery for pure economic loss can be understood as a rule for channeling claims through the parties that suffer physical injury. See Mario J. Rizzo, A Theory of Economic Loss in the Law of Torts, $11 \mathrm{~J}$. Legal Stud. 281 (1982). While Rizzo has been criticized for overstating the importance of the channeling explanation (see Robert L. Rabin, Tort Recovery for Negligently Inflicted Economic Loss: A Reassessment, 37 Stan. L. Rev. 1513, $1535 \mathrm{n} .72$ (1985)), his view contains a substantial element of truth. 
might have been one of form, not substance. Robins might only establish a standing rule (the charterer acting on its own does not have standing) and a default rule for sharing the recovery between two contractually linked parties (absent language to the contrary, only the owner recovers).

\section{Beyond the Bonus Value}

Even with that narrow reading, Robins presents some ambiguities. It has confused subsequent courts in cases that were very similar except that something other than the bonus value was at stake. In this section, I want to consider two such problems. In the first, the only difference from Robins is that the charter did not include a cesser of hire clause. In the second, the detained ship had contracted with fishermen whose compensation from the boat owner was based on a share of the catch.

\section{A. Hire Continues}

Suppose that there had been no cesser-of-hire (or rent abatement) clause. In that event, the owner would have suffered no financial harmit would have continued to receive payment. Should the wrongdoer be absolved? Should the owner recover the rent for the two weeks from both the charterer as per contract and the wrongdoer under tort law? Or should Robins's check ultimately wind up in Flint's pocket because it is either directly liable or under some trustee type argument? The reasoning of both Mack and Goddard would lead to the third outcome. Holmes's resolution is unclear.

The issues arose in Agwilines, Inc. v. Eagle Oil \& Shipping Co. ${ }^{76}$ During the Second World War, the U.S. government, as a charterer, requisitioned vessels for the war effort. The standard charter agreement required that the government pay half hire while the ship was undergoing repair. A ship was damaged and put out of service for nine days, and the owner sued for the loss of hire for that period. The commissioner and the district court held that the owner's recovery would be diminished by the amount that it received from the charterer while the ship was being repaired. In a divided opinion, Judge Learned Hand affirmed. ${ }^{77}$

Hand, it should be recalled, had joined Mack in his opinion in Robins

${ }^{76}$ Note 55 supra.

7 A similar case arose in the English courts in the aftermath of the First World War. A ship under requisition-time charter to the French government was damaged; the government had to continue paying hire while the ship was under repairs. The court held that neither the owner nor the charterer could recover; Chargeurs Reunis v. English \& Am. Shipping Co., 9 Ll.L.L.Rep. 464 (1921). 
two decades earlier. He appeared to be still smarting from having been overturned in the earlier case.

When the case was before us, we held that, although the charterer had no proprietary interest in the ship and no contract with the drydocker, the drydocker could not protect himself by the ordinary doctrine that a tortfeasor is not liable for remote damages, because the whole loss from detention of the ship was to be apprehended from his lack of care, whether the owner bore it all, or shared it with a charterer, and that, the whole loss being therefore a direct consequence of his negligence, he should not be allowed to cut down his liability. . . . To all of this the Supreme Court said "no." . . . Perhaps it was not necessary . . . to consider our argument that the owner might be treated as suing on behalf of the charterer; but the court did so and definitely repudiated it. . . . In the face of this decision we cannot see how we can do otherwise than affirm the decree at bar; if any change is to be made the Supreme Court must make it. ${ }^{78}$

In his dissent, Judge Charles Clark distinguished Robins, asserting that it only precluded a suit by the charterer. It did not prevent the owner from suing for damages. In answer to the claim that the owner had already been compensated for its losses by the continued payment of the charter hire, Clark argued that "payments or reparations of whatever nature which the injured party receives from a collateral source are, in the words of the courts, res inter alios acta, of no concern to the wrongdoer." This formulation leaves open the question of who ends up with the wrongdoer's damage payment-the vessel owner (collateral source rule) or the charterer.

Three decades later, the Fourth Circuit faced essentially the same case, except that the suit was brought by the charterer. ${ }^{80}$ Judge Haynsworth noted that, following Agwilines, the owner could not recover because it had received full charter hire while the vessel was being repaired. The charterer could recover, however, under his reading of Robins. Since Flint had not paid charter hire during the delay, its claim was "for loss of anticipated profits." 81 The charter could recover for loss of use (the charter hire) but not the lost profits (the bonus value). That the charterer did not have a property interest in the vessel was merely a technicality. As the dissent noted, with this reading, Robins turns on the measure of damages rather than on the notion that the charterer had no standing. ${ }^{82}$

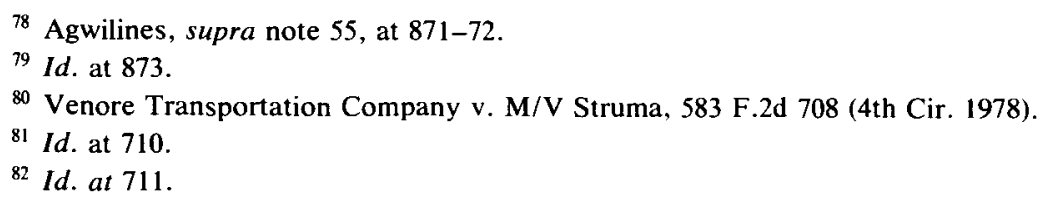


There is a significant distinction between Robins and the case in which the charterer continues to pay hire. In Robins the expected value of the bonus value at the time of entering into the charter was zero. The wrongdoer is liable to the owner for the charter price, and the charterer receives nothing. Sometimes this results in a windfall for the wrongdoer and sometimes a loss. But, on balance, the wrongdoers bear the costs of their actions, and the charterers are adequately compensated. If, however, the charterer must continue to pay hire, a rule that compensates the owner for its actual losses (that is, does not compensate for lost hire) and denies the charterer standing yields an unhappy outcome. The wrongdoers systematically are underassessed, and the charterers undercompensated. Either Clark's or Haynsworth's approach would avoid this outcome.

The response to Agwilines dramatically illustrates the error of the outcome. The charter form was subsequently revised in such a way as to make the wrongdoer liable to the charterer. The revised charter term was approved in M. \& J. Tracy, Inc. v. Tug Rowen Card, Card Towing Line ${ }^{83}$ The commissioner noted that the government "frankly concedes that Clause 4 is a revised form which was prompted by the Agwilines decision in the Court of Appeals." 84 Notwithstanding the improbability of this chronology, ${ }^{85}$ it is clear that the Agwilines litigation triggered a search for a mechanism that would assess the wrongdoer the damages arising from the detention.

Under the amended clause the obligation to pay hire would cease if a third party was liable. ${ }^{86}$ The charterer would indemnify the owner and continue to make payments. The charterer would then be subrogated to

831953 A.M.C. 1700.

${ }^{84}$ Id. at 1704 .

85 The Tracy collision took place on February 21, 1945; the amended time charter was dated June 5, 1944. The Agwilines detention occurred in June, 1943. Liability was determined in the district court on August 18, 1944, and a commissioner was appointed at that date to assess damages; the commissioner's decision was handed down on February 20 , 1945. The decisions of the district court and appeals court were on March 29, 1945, and January 10, 1946, respectively. Obviously, the charter term was amended long before the appeals court acted.

${ }^{86}$ The amended Clause 4 read as follows: "In the event that the Vessel is detained ... for which detention such third parties are or may be liable ... then for such period of detention the Charterer's obligation to the Owner for hire and for other sums otherwise accruing hereunder shall cease: Provided, however, that the Charterer shall indemnify and save the Owner harmless from any loss whatsoever by reason of the cessation of such obligations, and notwithstanding said cessation shall pay to the Owner a sum not less than the amount which would otherwise be payable to the Owner for such obligations in the same manner and to the same extent as if such cessation had not occurred, but on performance of this indemnity the Charterer shall immediately become subrogated, to the extent of such indemnity, to all rights whatsoever of the Owner to recover for such detention from or against such vessel, person, corporation, or others, and the Charterer shall be entitled to 
the owner. Moreover, the charterer could bring a suit in its own name or in the name of the owner. The owner agreed that it would assert and prosecute claims on behalf of the charterer with the charterer paying legal fees. The net result of all of this is that the charterer could sue the wrongdoer for the loss of hire.

The process of contracting around a rule that would yield an incorrect outcome illustrates a number of points. First, the parties can respond quickly when the rule seems clearly wrong. Second, it will often not be obvious what will work; the clause seems to give the charterer three bites at the apple-subrogation, suit in its own name, and the owner's promise to sue on the charterer's behalf. The redundancy probably reflected doubts about the efficacy of each. Third, the wrong outcome in Agwilines carried over to all other government requisition-time charters prior to June $1944 .{ }^{87}$ Moreover, the uncertainty about whether the new Band-Aid solved their problem was not resolved until 1953, eight years after the war ended. Fourth, a minor variant on this clause could have been appended to all time charters, including those with cesser of hire clauses. That is, a clause like this could have been used to contract around the Robins decision. The fact that it was not done, even after this innovative clause was approved by the courts, provides further evidence that the Robins outcome was correct.

Thus, there were three routes to the correct result: the owner recovers directly as a matter of law (Clark), the charterer recovers directly as a matter of law (Haynsworth), or the charterer recovers if the charter agreement were drafted cleverly so as to avoid the natural legal result. Clark's route strikes me as the cleanest route to the proper result. It is consistent with the precedent (Haynsworth required an extraordinary stretch), and it sets out the legal problem in simple terms. First, assess damages; second, divide the award.

\section{B. Sharing}

Suppose that the vessel damaged by Robins had been a fishing vessel that was then put out of service for two weeks. The vessel owner had

bring and maintain suit or suits thereon in its own name or in the name of the Owner as the Charterer may see fit: Provided, however, That on the written request of the Charterer, the Owner shall in each instance, assert and prosecute such claims in the name of the Owner, but for and on behalf of the Charterer and at the Charterer's expense, such claims to be in a sum not less than the amount of the indemnity paid by the Charterer" (id. at 1703).

${ }^{87}$ This problem could have been even worse if the government did not have the power to amend all the charters at once. Otherwise, the rule could have applied to all charters entered into before June 1944 and not amended. 
agreed to compensate the fishermen with a percentage of the proceeds of the sale of the fish caught after an allowance for certain expenses ${ }^{88} \mathrm{How}$ should the courts respond to a claim by the fishermen that they should be compensated for the payments they would have received had the vessel not been idled? The Ninth Circuit held in 1951 that this case was governed by Robins and denied recovery. ${ }^{89}$ Two years later, however, the court reversed itself in Carbone $v$. Ursich. ${ }^{90}$

Carbone cited a number of earlier opinions, including some that predate Robins, allowing the fishermen to recover from the tortfeasor either directly or by the owner of the vessel suing in trust for the fishermen. The court argued that the existence of the pre-Robins decisions suggested that Holmes meant for these decisions to remain unaffected by Robins: "As we now view the matter, it must be assumed that Mr. Justice Holmes, who wrote the opinion in the Robins Dry Dock case, was familiar with such cases as The Columbia, The Mary Steele, and Taber v. Jenny. ... It is noteworthy that the Robins Dry Dock case contains no internal evidence of an intention to reverse a course of prior decisions relating to the liability of persons in the position of the respondent for losses sustained by fishermen such as these appellants." 91 Perhaps Holmes was aware of these earlier cases. However, none of these cases was mentioned in any of the Robins briefs, and I find it a bit of a stretch to read Holmes's silence as implicit acquiescence. ${ }^{92}$ Nonetheless, Carbone can be distinguished from Robins.

Analytically, there are two separate routes toward rationalizing compensation for the fishermen. These depend on the extent to which the fishermen's share is viewed as payment for services already rendered or as payment for future effort. Carbone had elements of both the past and future compensation. The tortfeasor damaged the net, causing the fishermen to lose the fish that they had already captured; in addition, they were unable to fish for three days and sued to recover their projected

${ }^{88}$ This is a common way of compensating fishermen, sometimes called a "lay" plan. See Carbone v. Ursich, The Del Rio, 209 F.2d 178 (9th Cir. 1953) and some of the cases cited therein.

89 Borcich v. Ancich, 191 F.2d 392 (9th Cir. 1951).

90 Carbone, supra note 88.

91 Id. at 181. The cases cited are The Columbia, D.C.N.Y.1877, 6 Fed.Cas. No. 3,035, at 173; The Mary Steele, D.C.Mass. 1874, 16 Fed.Cas. No. 9, 226, at 1003; and Taber v. Jenny, D.C.D.Mass. 1856, 23 Fed.Cas. No. 13,720, at 605.

92 Carbone has been followed in a number of jurisdictions; see, for example, Miller Industries v. Caterpillar Tractor Co., 733 F.2d 813 (11th Cir. 1984). For criticism of Carbone, see Henderson v. Arundel Corporation, 262 F. Supp. 152, 159-60 (D. Md. 1966); and Casado v. Schooner Pilgrim, Inc., 171 F. Supp. 78 (D. Mass. 1959). The former questions Carbone's characterization of the pre-Robins case law. 
share for those three days. The argument for compensating the fishermen's past losses is clear-the case is essentially the same as Agwilines. The case for compensating the future losses is much weaker.

The easiest case is one in which the wrongdoer had caused the fishing vessel to lose some fish that had already been captured. ${ }^{93}$ If the wrongdoer only has to compensate the owner for the loss of its share, then it is systematically undercharged for the damage it causes. It differs from the Robins-type case in which the expected value of the bonus value is zero so that there is not a systematic undercharge. Moreover, the agreement between the owner and the fishermen does not provide an immediate measure of the value of the ship, as it did in Robins. In Robins, compensating the owner for the lost rental and not compensating the charterer had two virtues: the level of compensation was correct on average, and the contract rent provided a cheap measure of the expected damages. If the contract rent is in the form of a sharing formula, however, neither of these virtues remain.

Like Agwilines, the case presents two separate issues: the magnitude of the damages assessed against the tortfeasor and the division of those damages between the owner and the fishermen. The former is a matter of tort; the latter is (or ought to be) a matter of contract. There is no reason in principle that the contract between the fishermen and the owner could not allocate the entire award to one or the other. However, there is good reason to believe that they would not choose to do so. The sensible default rule would be to share the award according to the sharing formula specified in the contract between the owner and the fishermen.

An intermediate case presents a somewhat more difficult problem. Suppose that employees engage in prevoyage activities that were to have been compensated out of the receipts from the voyage or season. ${ }^{94}$ Their claim is, at base, a claim in contract against the owner. The employees provided effort that enhanced the value of the owner's vessel; the tortfeasor's act then reduced the value of the vessel. Again, the vessel owner

${ }^{93}$ In Taber v. Jenny, supra note 91 , one vessel had captured a whale, which was stolen by a second vessel. The owner of the first vessel and the fishermen each sued to recover their respective shares. The owner recovered and the remaining issue was whether the fishermen were entitled to recover their "lay" or "share."

${ }^{94}$ Miller Industries involved a substantial backward looking component: "The court ... awarded damages to ... a crew member . . . and to the shipowners as trustee for the other crew members' share of the lost catch. His award was based on a finding that the crew members' sole compensation for their work, including preparatory work during the summer and early fall and the sailing of the vessel from Mobile to Seattle, was based on a percentage of the gross catch (eight percent for each of the four crew members and seventeen percent for the Captain)" (Miller Industries, et al. v. Caterpillar Tractor Co., 733 F.2d 813, 816 (1984)). 
should have an action against the wrongdoer for the reduced value of the vessel. The sharing rule is not relevant for determining the liability. It would only come into play in dividing the award. What makes this case more difficult is that the fishermen's claim is no longer unambiguously backward looking. If the resolution of the claim is different for forwardand backward-looking claims, then there is less reason to believe that a simple default rule-give the fishermen their share of the award-would serve well for the mixed case.

Let us, therefore, turn to the harder case in which the fishermen's share is primarily compensation for labor not yet performed-that is, it is a substitute for future wages. Suppose, to take the extreme case, that the owner of a damaged vessel had not yet entered into a contract with any fishermen. The simple measure of the owner's damages would be the expected market value of the fish that would have been caught less the costs to be incurred in capturing them, which would include the costs of the fishermen's time and effort. ${ }^{95}$ Any compensation received by the fishermen would not be a matter of dividing a tortfeasor's fixed liability between the fishermen and the owner. The fishermen's compensation, if any, would be in addition to the owner's. This is obvious if the owner had hired no fishermen at the time of the accident, as in the hypothetical example. It is equally true if the fishermen had already been hired at a fixed fee, a fixed wage, or with a sharing contract. Their claim would be for earnings forgone. The fishermen are in the same position as employees who are temporarily laid off because a tortfeasor damaged their factory. ${ }^{96}$ The form of their compenseation has nothing to do with the merits of their claim.

The backward-looking case, like Robins and Agwilines, essentially involved measurement of a fixed loss and the division of that loss between two (or more) claimants. How would rational parties choose to divide a potential claim of fixed, but unknown size, when they enter into a contract? And how could they assure that their contractual relationship did not result in a systematic reduction in the magnitude of their joint claim?

\footnotetext{
95 Note that this does not imply that the vessel owner has a property right in the as-yetuncaptured fish. This is just a way to estimate the highest and best use of a physical asset that is not easily priced (the fishing vessel) during the period that it is out of service. It is analogous to valuing a damaged hotel by the expected net revenues, even though the hotel does not own its customers.

96 "IS]uppose a fishing vessel were sunk outright. Would all members of the crew be entitled to compensation until they obtained new employment, or if that employment were on a less profitable ship, for the difference? I believe the fundamental principles of liability should be the same, whether employees are fishermen, or factorymen" (Casado v. Schooner Pilgrim, Inc., supra note 92).
} 
The forward-looking case raises a completely different set of issues. What, for example, is the basis for their claim: fairness? good faith reliance? Further, should the employees be required to mitigate their damages by taking other employment? They could not mitigate in the backward-looking case since their loss would be independent of their future behavior. But mitigation is clearly a possibility in a forwardlooking case. Indeed, if the employees have no specific human capital, their only losses would be transitional costs-their downtime while moving from the injured employer to another.

Should employees be compensated for their future wages if a vessel were destroyed? Should it matter if they had skills that were uniquely related to that particular vessel or if their skills were easily transferred to alternative employment. Should their compensation depend on their efforts to mitigate damages? These are hard questions, and I do not intend to resolve them here. For my purposes, it is sufficient to note that resolving them requires an entirely different intellectual apparatus than the one employed in this article.

\section{Concluding Remarks}

Tort law is under constant pressure to extend the boundaries of what constitutes a compensable injury. The economic loss doctrine has been a significant factor in delimiting the boundaries, and the Robins decision has been a key element of the doctrine. My analysis of Robins suggests that, analytically, it differs fundamentally from the bulk of the cases that raise the economic loss question. To decide that, say, Exxon should not have to compensate Alaskan innkeepers because Robins did not have to compensate Flint is a non sequitur. Since courts are at least somewhat reluctant to being bound by ill-fitting precedent, the analysis might be taken as an invitation for the assault on yet another citadel against the expansion of tort liability.

However, the moral of this story is not that the Robins rule results in bad decisions. Indeed, I suspect that the rule's denial of recovery is often correct, despite the fact that the Robins analysis would be irrelevant in the particular context. My point is that the rule has to be rethought. We require some intellectual apparatus for evaluating the myriad of claims for recovery of mere economic loss. The analysis of Robins illuminates one small corner of the problem. By breaking the problem down into a series of such manageable problems, I hope to provide the building blocks for a more satisfactory disposition of claims for economic losses. 